\title{
Volume 23, Number 2
}

\section{April 1991}

\section{Journal of}
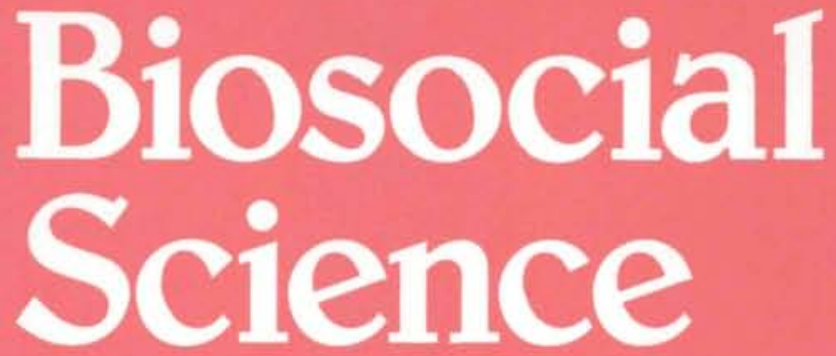

\section{Incorporating Biology and Society of the}

Galton Institute

\section{Published by the Biosocial Society}

\section{Cambridge, England}


Editor: C. G. N. Mascie-Taylor

\section{Editorial Advisory Panel}

\section{J. L. Boldsen \\ D. A. Coleman \\ P. C. L. Diggory}
G. A. Harrison
A. G. Hill
G. W. Lasker
D. M. Potts

\author{
P. F. Selman \\ S. J. Ulijaszek \\ V. Reynolds
}

For the Galton Institute

J. A. Beardmore R. Chester

Review Editor
Erica Haimes

Associate Editor

Consultant

M. A. Herbertson

D. F. Roberts

\section{Notice to Contributors}

The Joumal of Biosocial Science publishes original papers, short reports: reviews. lectures. and book reviews dealing with social aspects of human biology. including reproduction and its control. gerontology. ecology. genetics and applied psychology: with biological aspects of the social sciences. including sociology social anthropology. education and criminology: with social and biological elements of nutrition. growth and development. health and epidemiology: and with biosocial aspects of demography. Preference will be given to material which is clearly interdisciplinary.

Papers are considered for publication on the understanding that they have not been, and will not be. published elsewhere in whole or in part. and that. where customary. thes have been approved for publication by the relevant Head of Department. The Editor is not responsible for any loss of or damage to manuscripts or illustrations and his decision on all editorial matters is final. This Journal is covered by Current Conents, Biological Abstracts, Pstchological Abstracts and Population Index.

Manuscripts should be sent in duplicate to the Editor. Joumal of Biosocial Siience. Department of Biological Anthropology. Downing Street. Cambridge CB? 3DZ. They should be clearly typewritten. on one side of the paper only. with a $1^{\prime}$, inch margin. and be double-spaced and in the English language. Spelling should follow that of the Concive Oxtord Dictionurt. The Editor reserves the right to make minor literary emendations in the final editing. but manuscripts will not be altered substantially without consultation with the author or marked unless the paper is thought provisionally to be acceptable. The author is responsible for the accuracy of quotations. tabular matter and references. Manuscripts or tables prepared on dot-matrix printers are not acceptable.

Mamuscripts should bear the title of the paper. name of the Institution where the work was done. the present postal address of the author if different from that of the Institution. and a short running head of not more than 50 letters. Titles should be brief. A short summary should precede the text. Acknowledgments should be made in a separate section.

Diagrams must be numbered and should bear the author's name, short title of the paper and figure number on the back Captions should be typed on a separate sheet.

Tables should be typed on separate sheets. be given Arabic numbers and be headed by adequate captions. Their approximate position in the text should be indicated by a note in the margin. They should not exceed in size the equivalent of one page of print. Weights and measurements should be given in metric units. Standard abbreviations should be used $(\mu \mathrm{g} . \mathrm{mg} . \mathrm{g} . \mathrm{kg}$ : $\mathrm{ml}$. l: $\left.\mathrm{mm}, \mathrm{cm}, \mathrm{m}, \mathrm{km},{ }^{\circ} \mathrm{C},{ }^{\prime \prime},<_{,}>, \mathrm{hr}, \mathrm{min}\right)$. Abbreviations should not be followed by, and initials need not be separated by, full points (eg. FPA). Mean values should. where possible. be accompanied by standard errors or similar statistical indications of variance.

References in the text should be given in the manner that is standard in the Journal. Titles of journals should be abbreviated according to the World List of Sciemific Periodicals, 4 th edn (1964) and its supplements, and as also given in World Medical Periodicals. An unpublished paper should not be cited unless it is already in press.

Debate. A Dehate section is reserved for comments on papers appearing in previous issues. Authors whose papers are involved will be given an opportunity to reply for simultaneous publication. The Editor's decision as to publication of comments is final. Comments. not exceeding 500 words (one printed page). should be sent to the Editor.

Proofs will be sent to contributors for minor corrections, and should be returned to the Editor within one week. Major alterations to the text will be accepted only at the author's expense. The date of receipt given at the end of the paper is that on which the script as published was received or agreed.

Offprints. A copy of the issue of the Journal in which the paper appears will be supplied free to the author, or, where there are two or more, to the author responsible for ordering offprints. Offprints may be purchased by ordering on the form sent out with the proofs.

c Biosocial Society. With the exception of abstracts of no more than 300 words. no part of this publication may be reproduced or stored in a retrieval system in any form or by any means without the permission of both the Biosocial Society and the author. 


\section{JOURNAL OF BIOSOCIAL SCIENCE}

The Journal of Biosocial Science is published by the Biosocial Society and distributed by the Portland Press (formerly the Biochemical Socicty Book Depot).

Orders. parments and enquiries regarding distribution should be sent to:

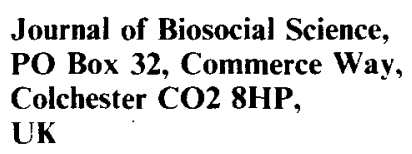

For 1991 (Volume 23) there will be four issues, published in January, April, July and October.

The subscription rates for 1991 are:

$\begin{array}{lccc} & \begin{array}{c}\text { UK and } \\ \text { overseas } \\ \text { (surface mail) }\end{array} & \begin{array}{c}\text { USA, Canada } \\ \text { and Mexico }\end{array} & \begin{array}{c}\text { Japan only } \\ \text { (by air) }\end{array} \\ \text { (by ASP) } \\ \text { Annual subscription } & £ 55.00 & \$ 105.00 & £ 63.00 \\ \text { Per part } & £ 17.00 & \$ 29.00 & £ 19.00\end{array}$

To avoid a break in continuity subscribers are asked to place their orders, either direct or through an agent, by mid-December. Should a Standing Order be required, this should be indicated in the order instructions and an invoice will then be sent automatically in the last quarter of each year.

Limited numbers of earlier issues are available. Volumes 1-10 (1969-78, original price $£ 111.50$ )

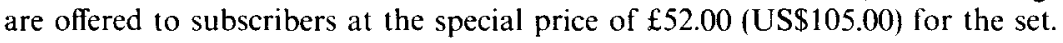

Manuscripts for publication and books for review should be sent to:

The Editor,

Journal of Biosicial Science,

Department of Biological Anthropology,

Downing Street,

Cambridge CB2 3DZ,

UK

Second-class postage paid in Rahway, New Jersey, USA.

Postmaster. Send address corrections to: Journal of Biosocial Science, c/o Mercury Airfreight International Inc., 2323 Randolph Avenue, Avenel, NJ 07001, USA (US mailing agent). 


\section{JOURNAL OF BIOSOCIAL SCIENCE}

Vol.23, No. 2

Ram Hari Aryal

G. Biondi

Lee Cronk

P. Feldblum

Erica Haimes

J. C. Haskey

B. Ineichen

N. Krayacich de Oddone

G. Lasker

Y. Motohashi

C. Panter Brick

E. Perrotti

P. Phillimore

M. Potts

P. Raspe

J. L. Rodgers

D. C. Rowe

M. G. Shedlin

E. O. Udjo

S. J. Ulijaszek

M. Welsh
Contributors

April 1991

Assistant Secretary, Parliamentary Secretariat, Kathmandu, Nepal

p. 167

Research Scientist, Department of Animal and Human Biology, University La Sapienza, Rome

p. 129

Assistant Professor, Department of Anthropology, Texas A \& M University, College Station, Texas, USA

p. 229

Associate Director, Family Health International, NC, USA p. 201

Lecturer, Department of Social Policy, University of Newcastle upon Tyne

p. 253

Statistician, Social Statistics Unit, Demographic Analysis and Vital Statistics Division, OPCS, London

p. 179

Lecturer in Public Health Medicine, Charing Cross and Westminster Medical School, London

President, Paraguyan College of Chemical Pharmacists, Asunción p. 201

Emeritus Professor, Department of Anatomy and Cell Biology, Wayne State University, Detroit, USA

Associate Professor, Department of Public Health, Tokyo Medical and Dental University, Japan

p. 221

Lecturer, Department of Anthropology, University of Durham

Research Fellow, Department of Animal and Human Biology, University La Sapienza, Rome

Senior Research Associate, Centre for Urban and Regional Development Studies, University of Newcastle upon Tyne p. 249

President Emeritus, Family Health International, NC, USA p. 201 Visiting Fellow, Department of Biological Anthropology, University of Cambridge

Associate Professor, Department of Psychology, University of Oklahoma, Norman, USA

Associate Professor, School of Family and Consumer Resources, University of Arizona, Tucson, USA

President, Sociomedical Resource Associates, Westport, Connecticut. USA

p. 201

Postdoctoral Fellow, University of Zimbabwe, Harare p. 155

University Assistant Lecturer, Department of Biological Anthropology, University of Cambridge

p. 251

Associate Director, Family Health International, NC, USA p. 201 